\title{
DIMENSI RESIKO OPERASIONAL TERHADAP RETURN ON ASSET (ROA) PADA BANK SYARIAH YANG TERDAFTAR DI BEI (BURSA EFEK INDONESIA) PERIODE TAHUN 2015 - 2017
}

\author{
Siti Hayati Efi Friantin
}

\author{
STIE Adi Unggu Bhirawa Surakarta \\ Email efriantin@stie-aub.ac.id
}

\begin{abstract}
ABSTRAKSI
Penelitian ini bertujuan untuk menguji dimensi resiko operasional terhadap return on asset (ROA) pada bank syariah yang terdaftar di BEI (Bursa Efek Indonesia) periode tahun 2015 - 2017. Dimensi resiko operasional meliputi Non Performing Financing (NPF), Biaya Operasional per Pendapatan Operasional (BOPO), dan Financing to Deposit Ratio (FDR) terhadap Return On Asset (ROA) sebagai proksi dari profitabilitas Bank Umum Syariah diIndonesia periode 2015-2017. Data yang digunakan dalam penelitian ini diperolehdari data Laporan Keuangan Publikasi Tahunan Bank Umum Syariah periode 2015-2017. Populasi dalam penelitian ini adalah 12 Bank Umum Syariah diIndonesia.Teknik analisis yang digunakan dalampenelitian ini adalah regresi linear berganda yang bertujuan untuk memperolehgambaran yang menyeluruh mengenai hubungan antara variabel.Sedangkan ujiasumsi klasik yang digunakan dalam penelitian ini meliputi uji autokorelasi, ujinormalitas, uji multikolonieritas, dan uji heteroskedastisitas. Hasil penelitian menunjukkan bahwa NPF berpengaruh negatif tidak signifikan terhadap ROA.Sedangkan variabel BOPO dan FDR berpengaruh positif dan signifikan terhadap ROA Bank Umum Syariah.Hasil penelitian ini diharapkan dapat menjadi pedoman bagi manajemen Bank Umum Syariah dalam mengelola perusahaan.Nilai Adjusted $R$-Square pada model regresi adalah 0,352 yang menunjukkan kemampuan variabel independen yaitu bahwa Non Performing Financing (NPF), Beban Operasional per Pendapatan Oprasional (BOPO), dan Financing to Deposite Ratio (FDR) dalam menjelaskan variabel dependen yaitu profitabilitas perusahaan Return On Asset (ROA) adalah sebesar $35,2 \%$ sedangkan sisanya sebesar $64,8 \%$ dijelaskan variabel lain yang tidak termasuk dalam penelitian.
\end{abstract}

Kata kunci: Non Performing Financing (NPF), Biaya Operasional per Pendapatan Operasional (BOPO), Financing to Deposit Ratio (FDR), Return On Asset (ROA)

\section{ABSTRACT \\ "Dimentiont Operational Risks to Returrn On Assets (ROA) at Sharia Banks listed on Indonesia Stock Exchange (IDX) at Period Year 2015-2017}

This study aims to examine the effect of Dimentiont Operational Risks ( Non Performing Financing (NPF), Operational Cost per Operating Income (BOPO), and Financing to Deposit Ratio (FDR)) to Return On Assets (ROA) as a proxy of profitability of Sharia Commercial Bank in Indonesia period 2015-2017. The data used in this research is obtained from the Annual Sharia Bank Annual Sharia Financial Statement data for period 2015-2017. The population in this study are 12 Sharia Commercial Banks in Indonesia. The analytical technique used in this research is multiple linear regression that aims to obtain a comprehensive description of the relationship between variables. While the classical assumptions used in this study include the autocorrelation test, ujinormalitas, multicolonierity test, and heteroscedasticity test. The results showed that the NPF has a negative effect is not significant to ROA.Sedangkan BOPO and FDR variables have positive and significant impact on ROA Syariah Commercial Bank. The results of this study is expected to be a guide for the management of Sharia Commercial Bank in managing the company. The value of Adjusted R-Square in regression model is 0.352 which shows the ability of independent variable that is Non Performing Financing (NPF), Operational Expense per Oprasional (BOPO) and Financing to Deposite Ratio (FDR) in explaining the dependent variable that is profitability of company Return On Asset (ROA) is $35.2 \%$ while the rest of $64.8 \%$ described other variables that are not included in the study.

Keywords: Non Performing Financing (NPF), Operating Expenses on Oprasional Revenue ( (BOPO), Financing to Deposit Ratio (FDR), Return On Asset (ROA

\section{PENDAHULUAN}

Bank, dalam menjalankan aktivitasnya berfungsi sebagai lembaga intermediasi (financial intermediary) yaitu lembaga keuangan yang berfungsi sebagai perantara pihak yang kelebihan dana dengan pihak yang kekurangan dana. Dalam Undang-Undang No. 7 Tahun 1992 tentang perbankan sebagaimana telah diubah dengan Undang-Undang No. 10 Tahun 1998 tertulis pula bahwa bank umum melaksanakan kegiatan usaha secara konvensional dan atau berdasarkan prinsip 
syariah (bank syariah). Perbedaan mendasar antar bank konvensional dan bank syariah adalah adanya larangan bunga dalam bank syariah sebagaimana sistem bunga yang dianut oleh bank konvensional.

Eksistensi perbankan syariah di Indonesia saat ini semakin meningkat sejak adanya Undang Undang No. 21 Tahun 2008 Tentang Perbankan Syariah yang memberikan landasan operasi yang lebih jelas bagi bank syariah.Hal ini tampak dari perkembangan kelembagaan perbankan syariah yang semakin meningkat sejak dikeluarkannya Undang-Undang No. 7 Tahun 1992 tentang Perbankan.Dimana pada tahun 1992, hanya ada satu Bank Umum Syariah yang beroperasi di Indonesia yaitu Bank Muamalat Indonesia dan sembilan Bank Pembiayaan Rakyat Syariah. Perkembangan kelembagaan bank syariah menunjukkan bahwa dilakukannya amandemen UU No. 7 tahun 1992 menjadi UU No. 10 tahun 1998 direspon positif oleh pelaku industry perbankan dengan adanya penambahan satu Bank Umum Syariah dan 1 Unit Usaha Syariah, serta 69 BPRS pada tahun 1999. Sehingga pada tahun 2010, jumlah Bank Umum Syariah yang beroperasi menjadi 11, diikuti oleh 23 Unit Usaha Syariah, dan 150 BPRS. Eksistensi bank syariah juga didorong oleh tingginya minat masyarakat untuk menempatkan dananya di bank syariah karena dikarenakan produk dana perbankan syariah memiliki daya tarik bagi deposan mengingat nisbah bagi hasil dan margin produk tersebut masih kompetitif dibanding bunga di bank konvensional (LPPS, 2009).

Profitabilitas dapat dikatakan sebagai salah satu indikator yang paling tepat untuk mengukur kinerja suatu perusahaan. Rasio yang biasa digunakan untuk mengukur kinerja profitabilitas atau rentabilitas adalah Return OnEquity (ROE) dan Return On Asset (ROA). Alasan dipilihnya Return OnAsset (ROA) sebagai ukuran kinerja adalah karena ROA digunakan untuk mengukur kemampuan manajemen bank dalam memperoleh keuntungan secara keseluruhan.Dendawijaya (2003) menambahkan semakin besar ROA bank, semakin besar pula tingkat keuntungan yang dicapai bank tersebut dan semakin baik pula posisi bank tersebut dan segi penggunaan aset.

Non Performing Financing (NPF) merupakan rasio keuangan yang bekaitan dengan risiko kredit.Non Performing Financing adalah perbandingan antara total pembiayaan bermasalah dengan total pembiayaan yang di berikan kepada debitur. Rasio Non Performing Financing analog dengan Non Performing Loan pada bank konvensional.Karena pada bank syariah tidak mengenal adanya pinjaman namun menggunakan istilah pembiayaan.NPL mencerminkan risiko kredit, semakin kecil NPL semakin kecil pula risiko kredit yang ditanggung pihak bank (Nusantara, 2009).

BOPO atau Operational Efficiency Ratio merupakan perbandingan antara total biaya operasi dengan total pendapatan operasi. Rasio ini digunakan untuk mengukur tingkat efisiensi dan kemampuan bank dalam melakukan kegiatan operasinya (Dendawijaya, 2003).

Financing to Deposit Ratio (FDR) analog dengan Loan to Deposit Ratio (LDR) pada bank konvensional, merupakan rasio yang digunakan untukmengukur tingkat likuiditas bank yang menunjukkan kemampuan bank untukmemenuhi permintaan kredit dengan menggunakan total aset yang dimilikibank (Dendawijaya, 2003).

Perumusan masalah adalah sebagai berikut:1. Apakah Non Performing Financing berpengaruh terhadap Return On Asset pada Bank Syariah yang terdaftar di Bursa Efek Indonesia? 2.Apakah Beban operasional per Pendapatan Operasional berpengaruh terhadap Return On Asset pada Bank Syariah yang terdaftar di Bursa Efek Indonesia? 3. Apakah Financing To Deposit Rasio berpengaruh terhadap Return On Asset pada Bank Syariah yang terdaftar di Bursa Efek Indonesia?.

Tujuan penelitian ini adalah sebagai berikut: 1. Memberi bukti empiris pengaruh aspek Non Performing Financing (NPF) berpengaruh terhadap Return On Asset (ROA) Bank Syariah yang terdaftar di Bursa Efek Indonesia.2. Memberikan bukti empiris pengaruh Beban Operasional per Pendapatan Oprasional (BOPO) berpengaruh terhadap Return On Asset (ROA) Bank Syariah yang terdaftar di Bursa Efek Indonesia.3. Memberikan bukti empiris pengaruh Financing to Deposite Ratio $(F D R)$ berpengaruh terhadap Return On Asset (ROA) Bank Syariah yang terdaftar di Bursa Efek Indonesia.

\section{METODE PENELITIAN}

Data yang digunakan pada penelitian ini adalah data kuantitatif, yaitu data yang diukur dalam suatu skala numerik (angka). Jenis data yang digunakan dalam penelitian ini merupakan data sekunder yang diperoleh dari Laporan Keuangan Publikasi Tahunan periode tahun 2015 hingga 2017 yang diterbitkan oleh Bank Umum Syariah dalam website resmi Bank Indonesia dan website resmi masing-masing bank.

Populasi yang digunakan dalam penelitian ini adalah seluruh Bank Umum Syariah yang terdapat di Indonesia hingga tahun 2017 .Jumlah Bank Umum Syariah yang ada hingga tahun 2017 sebanyak 12 bank.Teknik sampling yang digunakan yaitu metode purposive sampling.Kriteria pemilihan sampel yang diajukan terdiri dari: 1. Bank Umum Syariah 
di Indonesia, 2. Bank yang diteliti masih beroperasi pada waktu penelitian, 3. Tersedia laporan keuangan tahunan pada periode waktu penelitian, dan 4.Bank yang diteliti sudah menjadi Bank Umum Syariah dalam kurun waktu penelitian.

Variabel dependen yang digunakan adalah Return On Asset (ROA). Rasio ini menunjukkan kemampuan manajemen bank dalam menghasilkan laba dari pengelolaan asset yang dimiliki (Yuliani, 2007). Return On Asset dirumuskan sebagai berikut:

$$
\mathrm{ROA}=\frac{\text { LABA BERSIH SETELAH PAJAK }}{\text { TOTAL AKTIVA }}
$$

Variabel independen yaitu: NPF, BOPO, dan FDR. 1. Non Performing Financing (NPF) Non Performing Financing (NPF) merupakan rasio keuangan yang menunjukkan risiko pembiayaan yang dihadapi bank akibat pemberian pembiayaan dan investasi dana bank pada portofolio yang berbeda

(Kuncoro 2002).

$$
\mathrm{NPF}=\frac{\text { PEMBIAYAAN BERMASALAH }}{\text { TOTAL PEMBIAYAAN }} \times 100 \%
$$

2. BOPO merupakan perbandingan antara besarnya beban operasional dengan pendapatan operasional yang diperoleh oleh bank. Satuan pengukurannya dalam bentuk persen dan untuk mengukurnya digunakan rumus sebagai berikut (Dendawijaya, 2009):

$$
\text { BOPO }=\frac{\text { BIAYA OPERASIONAL }}{\text { PENDAPATAN OPERASIONAL }}
$$

3. Financing to Deposit Ratio adalah perbandingan antara pembiayaan yang diberikan oleh bank dengan dana pihak ketiga yang berhasil dikerahkan oleh bank (Muhammad, 2005). Semakin rendah FDR menunjukkan kurangnya efektifitas bank dalam menyalurkan kredit sehingga ROA juga akan semakin rendah. Hasbi (2011)

$$
\mathrm{FDR}=\frac{\text { TOTAL BIAYA }}{\text { TOTALDANAPIHAKKETIGA }} X 100 \%
$$

\section{HASIL PENELITIAN DAN PEMBAHASAN}

\section{Deskripsi Data}

Data yang digunakan pada penelitian ini adalah data sekunder yang diperoleh dari laporan keuangan tahunan pada perbankan Syariah dan diperoleh dari situs Bursa Efek Indonesia (BEI) tahun 2015-2017 (www.idx.co.id).

\section{Hasil Uji Statistik Deskriptif}

Berdasarkan hasil uji statistik deskriptif diperoleh sebanyak 36 data observasi yang berasal dari jumlah sampel perbankan di Indonesia selama kurun waktu 2015-2017.Sampel yang berjumlah 12 yang memiliki data yang lengkap untuk kepentingan penelitian. 
Tabel 1

Hasil Uji Descriptive Statistics

\begin{tabular}{|l|r|r|r|r|r|}
\multicolumn{7}{|c|}{ De scriptive Statistics } \\
\hline NPF & \multicolumn{1}{|c|}{ N } & \multicolumn{1}{c|}{ Mnimum } & Maximum & \multicolumn{1}{c|}{ Mean } & Std. Deviation \\
BOPO & 36 &, 10 & 43,99 & 6,3308 & 8,86968 \\
FDR & 36 & 69,62 & 192,60 & 100,0078 & 23,66344 \\
ROA & 36 & 79,19 & 157,77 & 95,0233 & 14,51434 \\
Valid N (listw ise) & 36 & $-8,09$ & 20,13 & 1,8297 & 3,96356 \\
\hline
\end{tabular}

Sumber: data tahun 2017.

Berdasarkan tabel 1 dapat dikatakan bahwa jumlah sample sebanyak 36.NPF mempunyai nilai minimum sebesar 0,10 dan nilai maximum 43,99 sementara nilai rata-rata 6,3308 dengan standar deviasi 8,86968, ini berarti nilai mean lebih besar dari standar deviasi maka penyebaran data variabel Non Performing Financing (NPF) terdistribusi merata. Nilai komisaris independen terendah dimiliki oleh PT. BCA Syariah.dan nilai tertinggi dari PT. May Bank Syariah..

Selanjutnya Beban Operasional per Pendapatan Oprasional (BOPO) mempunyai nilai minimum sebesar 69,62 dan maximum sebesar 192,60sementara nilai rata-rata 100,0078 dengan standar deviasi 233,66344, ini berarti nilai mean lebih kecil dari standar deviasi maka penyebaran data variabel BOPO terdistribusi tidak merata Nilai Beban Operasional pada Pendapatan Oprasional (BOPO) terendah dimiliki oleh PT. May Bank Syariah 2015 dan nilai tertinggi juga dimiliki oleh PT.May Bank Syariah 2016.

Financing to Deposite Ratio (FDR) memiliki nilai minimum sebesar 79,19 oleh PT. Bank Mandiri Syariah tahun 2016 dan nilai maximum 157,77 oleh PT. May Bank Syariah dengan nilai rata-rata 95,02333 sementara standar deviasi sebesar 14,51434, ini berarti nilai mean lebih besar dari standar deviasi maka penyebaran data variabel Financing to Deposite Ratio (FDR) terdistribusi merata.

Return On Asset mempunyai nilai minimum sebesar -8,09 oleh PT. Bank Jabar Banten Syariah tahun 2016 dan nilai maximum sebesar 20,13 oleh PT. May Bank Syariah . tahun 2016 sementara itu nilai rata-rata senilai 1,829 dengan nilai standar deviasi sebesar 3,96356, ini berarti nilai mean lebih kecil dari standar deviasi maka penyebaran data variabel ROAterdistribusi tidak merata.

\section{Hasil Pengujian Asumsi Klasik}

Uji Autokorelasi

Tabel 2

Hasil Uji Autokorelasi

\begin{tabular}{|c|c|c|c|c|c|}
\hline \multicolumn{6}{|c|}{ Mode I Sum marb } \\
\hline Model & $\mathrm{R}$ & R Square & $\begin{array}{l}\text { Adjusted } \\
\text { R Square }\end{array}$ & $\begin{array}{l}\text { Std. Error of } \\
\text { the Estimate }\end{array}$ & $\begin{array}{l}\text { Durbin- } \\
\text { Wats on }\end{array}$ \\
\hline 1 & $638^{a}$ & 408 &, 352 & 1,05592 & 1,857 \\
\hline
\end{tabular}

Hasil uji autokorelasi pada tabel 2 dapat diketahui bahwa nilai Durbin Watson menunjukkan angka sebesar 1,857. Angka DW berada diantara 1,5 sampai 2,0 artinya dari pengujian ini menyatakan bahwa tidak terjadi autokorelasi antar variabel. 


\section{Uji Normalitas}

TABEL 3

Hasil Uji Normalitas

One-Sample Kolmogorov-Smirnov Test

\begin{tabular}{|ll|r|r|r|r|}
\hline & & \multicolumn{1}{|c|}{ NPF } & \multicolumn{1}{c|}{ NPF } & \multicolumn{1}{c|}{ BOPO } & \multicolumn{1}{c|}{ ROA } \\
\hline $\mathrm{N}$ & & 36 & 36 & 36 & 36 \\
Normal Parameters a,b & Mean & 1,2686 &, 6603 &, 6587 &, 0369 \\
& Std. Deviation & 1,14670 &, 02747 &, 01265 & 1,31178 \\
Most Extreme & Absolute &, 154 &, 220 &, 217 &, 113 \\
Differences & Positive &, 154 &, 143 &, 217 &, 071 \\
& Negative &,- 133 &,- 220 &,- 111 &,- 113 \\
Kolmogorov-Smirnov Z & &, 922 & 1,320 & 1,300 &, 675 \\
Asymp. Sig. (2-tailed) & &, 363 &, 061 &, 068 &, 752 \\
\hline
\end{tabular}

a. Test distribution is Normal.

b. Calculated from data.

Hasil uji normalitas dalam penelitian ini menggunakan uji One-Sample Kolmogrov-Smirnov.Terlihat bahwa nilai Asymp.Sig (2-tailed) semua variabel bernilai signifikansi diatas 0,05 yang berarti nilai residual terdistribusi secara normal atau memenuhi asumsi klasik.

\section{Uji Multikolinearitas}

TABEL 4

Hasil Uji Multikolonier

Coefficients

\begin{tabular}{|c|c|c|c|c|c|c|c|c|}
\hline \multirow{2}{*}{\multicolumn{2}{|c|}{ Model }} & \multicolumn{2}{|c|}{$\begin{array}{c}\text { Unstandardized } \\
\text { Coefficients }\end{array}$} & \multirow{2}{*}{$\begin{array}{c}\begin{array}{c}\text { Standardized } \\
\text { Coefficients }\end{array} \\
\text { Beta }\end{array}$} & \multirow[b]{2}{*}{$t$} & \multirow[b]{2}{*}{ Sig. } & \multicolumn{2}{|c|}{ Collinearity Statistics } \\
\hline & & $\mathrm{B}$ & Std. Error & & & & Tolerance & VIF \\
\hline \multirow[t]{4}{*}{1} & (Constant) & $-37,656$ & 8,183 & & $-4,602$ &, 000 & & \\
\hline & NPF &,- 220 & ,178 &,- 193 & $-1,235$ & ,226 & ,762 & 1,313 \\
\hline & BOPO & 1,874 & ,659 & ,434 & 2,844 &, 008 & ,796 & 1,257 \\
\hline & FDR & 6,484 & 1,501 & ,647 & 4,320 &, 000 & ,825 & 1,212 \\
\hline
\end{tabular}

a. Dependent Variable: ROA

Pada tabel 4 menunjukkannilai VIF $<10$ dan nilai tolerance $>0,1$ pada semua variabel. Hal ini menunjukkan bahwa tidak terjadi multikolinearitas.

\section{Hasil Uji Heteroskedastisitas}

TABEL 5

Hasil Uji Heteroskedastisitas

Coefficients

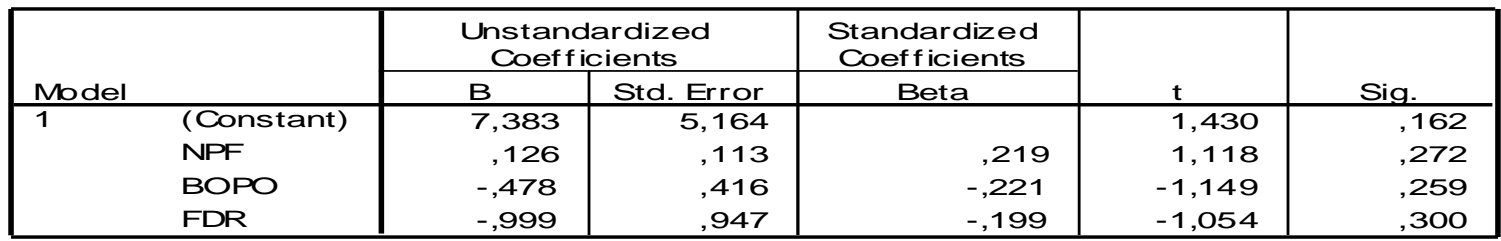

a. Dependent Variable: A bsut

Dari hasil uji heteroskedastisitas dapat diketahui bahwa nilai siginifikan masing-masing variabel lebih besar dari 0,05. maka dapat disimpulkan tidak ada masalah heteroskedastisitas dalam model regresi. 


\section{Model Regresi Linear Berganda}

TABEL 6

\begin{tabular}{|c|c|c|c|c|c|c|c|c|}
\hline \multicolumn{9}{|c|}{ Coefficients } \\
\hline \multirow[b]{2}{*}{ Model } & & \multicolumn{2}{|c|}{$\begin{array}{l}\text { Unstandardized } \\
\text { Coefficients }\end{array}$} & \multirow{2}{*}{$\begin{array}{c}\begin{array}{c}\text { Standardized } \\
\text { Coefficients }\end{array} \\
\text { Beta }\end{array}$} & \multirow[b]{2}{*}{$t$} & \multirow[b]{2}{*}{ Sig. } & \multicolumn{2}{|c|}{ Collinearity Statistics } \\
\hline & & $\mathrm{B}$ & Std. Error & & & & Tolerance & VIF \\
\hline & (Constant) & $-37,656$ & 8,183 & & $-4,602$ &, 000 & & \\
\hline & NPF &,- 220 & , 178 &,- 193 & $-1,235$ & ,226 & ,762 & 1,313 \\
\hline & BOPO & 1,874 &, 659 & ,434 & 2,844 & 008 & ,796 & 1,257 \\
\hline & FDR & 6,484 & 1,501 & ,647 & 4,320 &, 000 & ,825 & 1,212 \\
\hline
\end{tabular}

Sumber : data tahun 2017

Berdasarkan tabel 6, dapat ditentukan model regresi linier berganda yang dinyatakan dalam bentuk persamaan sebagai berikut:

$Y=-37,656-0,220 X_{1}+1,874 X_{2}+6,484 X_{3}$

Berdasarkan persamaan tersebut, dapat dilihat hubungan masing-masing variabel sebagai berikut:

1. Konstanta pada persamaan regresi linier berganda negatif sebesar -37,656 menyatakan bahwa Non Performing Financing (NPF), Beban Operasional per Pendapatan Oprasional (BOPO), dan Financing to Deposite Ratio (FDR) dianggap konstan maka Return On Asset menurun.

2. Nilai koefisien regresi untuk $\beta_{1}$ variabel Non Performing Financing (NPF) adalah negatif sebesar $-0,220$, berarti bahwa setiap peningkatan satu satuan Non Performing Financing NPF) maka Return On Aset (ROA) akan mengalami penurunan sebesar -0,220 dengan asumsi kondisi variabel bebas lainnya dianggap tetap. .

3. Nilai koefisien regresi untuk $\beta_{2}$ variabel Beban Operasional pada Pendapatan Oprasional (BOPO) adalah positif sebesar 1,874, berarti bahwa setiap peningkatan 1 satuan BOPOReturn On Aset (ROA) akan mengalami peningkatan sebesar 1,874 dengan asumsi kondisi variabel bebas lainnya dianggap tetap.

4. Nilai koefisien regresi untuk $\beta 3$ variabel Financing to Deposite Ratio (FDR) adalah positif sebesar 6,484, artinya apabilaFinancing to Deposite Ratio (FDR) meningkat sebesar 1 satuan, maka profitabilitas Return On Asset (ROA) akan meningkatsebesar 6,484 satuan.

\section{Pengujian Hipotesis}

\section{Uji Koefisien Determinasi (Adjusted $R$ Square)}

Uji koefisien determinasi $\left(\mathrm{R}^{2}\right)$ digunakan untuk melihat seberapa besar pengaruh variabel independen yaitu Non Performing Financing, Biaya Operasional Per Pendapatan Operasional, Dan Financing To Deposit Rasioterhadap variabel dependen, yaitu Return On Asset. Hasil pengujian dapat dilihat pada tabel 7berikut :

TABEL 7

\section{Hail Uji Koefisien Determinasi (Adjusted $R$ Square)}

Model Summary
\begin{tabular}{|l|r|r|r|r|r|}
\hline Model & R & R Square & $\begin{array}{l}\text { Adjusted } \\
\text { R Square }\end{array}$ & $\begin{array}{r}\text { Std. Error of } \\
\text { the Estimate }\end{array}$ & $\begin{array}{c}\text { Durbin- } \\
\text { Wats on }\end{array}$ \\
\hline 1 &, $638^{\mathrm{a}}$ &, 408 &, 352 & 1,05592 & 1,857 \\
\hline
\end{tabular}
a. Predictors: (Constant), FDR, BOPO, NPF
b. Dependent Variable: ROA

Sumber : data tahun 2017. 
Berdasarkan tabel 7, menunjukkan nilai Adjusted R-Square pada model regresi adalah 0,352 yang menunjukkan kemampuan variabel independen yaitu bahwa Non Performing Financing (NPF), Beban Operasional pada Pendapatan Oprasional (BOPO), dan Financing to Deposite Ratio (FDR) dalam menjelaskan variabel dependen yaitu profitabilitas perusahaan Return On Asset (ROA) adalah sebesar 35,2\% sedangkan sisanya sebesar 64,8\% dijelaskan variabel lain yang tidak termasuk dalam penelitian.

\section{Uji Signifikan Parsial (Uji t)}

\section{TABEL 8}

\section{Hasil Uji Signifikan Parsial (Uji t)}

Coefficients

\begin{tabular}{|c|c|c|c|c|c|c|c|c|}
\hline \multirow[b]{2}{*}{ Mod } & & \multicolumn{2}{|c|}{$\begin{array}{l}\text { Unstandardized } \\
\text { Coefficients }\end{array}$} & \multirow{2}{*}{$\begin{array}{c}\begin{array}{c}\text { Standardized } \\
\text { Coefficients }\end{array} \\
\text { Beta }\end{array}$} & \multirow[b]{2}{*}{$t$} & \multirow[b]{2}{*}{ Sig. } & \multicolumn{2}{|c|}{ Collinearity Statistics } \\
\hline & & B & Std. Error & & & & Tolerance & VIF \\
\hline \multirow[t]{4}{*}{1} & (Constant) & $-37,656$ & 8,183 & & $-4,602$ &, 000 & & \\
\hline & NPF &,- 220 & 178 &,- 193 & $-1,235$ & ,226 & ,762 & 1,313 \\
\hline & BOPO & 1,874 & ,659 & , 434 & 2,844 & ,008 & ,796 & 1,257 \\
\hline & FDR & 6,484 & 1,501 & ,647 & 4,320 &, 000 & ,825 & 1,212 \\
\hline
\end{tabular}

a. Dependent Variable: ROA

Non Performing Financing (NPF)mempunyai nilai signifikan sebesar 0,226>0,05 berdasarkan hasil tersebut maka dapat dikatakan bahwa NPF berpengaruh negatif tidak signifikan terhadap Return On Aset,.

Hasil Uji Pengaruh Non Performing Financing (NPF) Terhadap ROA pada Perbankan Syariah yang terdaftar di BEI periode 2015 -2017.

Beban Operasional per Pendapatan Oprasional (BOPO), mempunyai nilai signifikan sebesar 0,008< 0,05 berdasarkan hasil tersebut maka dapat dikatakan bahwa BOPO berpengaruh positif signifikan terhadap Return On Asset.

1. Hasil Uji Beban Operasional per Pendapatan Oprasional (BOPO), berpengaruh positif signifikan terhadap Return On Asset perbankan Syariah yang terdaftar di BEI tahun 2015 hingga 2017.

Hasil penelitian ini menunjukkan bahwa variabel Financing to Deposite Ratio (FDR) berpengaruh positif signifikan terhadap Profitabilitas perusahaan yang diukur dengan Return On Asset (ROA).

\section{Kesimpulan}

1. NPF berpengaruh negatif tidak signifikan terhadap profitabilitas perusahaan perabankan Syariah yang diukur dengan Return On Asset (ROA).

2. BOPO berpengaruh positif signifikan terhadap profitabilitas perusahaan perbankan Syariah yang diukur dengan Return On Asset (ROA).

3. FDR berpengaruh positif signifikan terhadap profitabilitas perusahaan yang diukur dengan Return On Asset (ROA).

4. Hasil Koefisiensi Determinasi $\left(\mathrm{R}^{2}\right)$ menunjukkan:

Nilai Adjusted $R$-Square pada model regresi adalah 0,352 yang menunjukkan kemampuan variabel independen yaitu bahwa Non Performing Financing (NPF), Beban Operasional pada Pendapatan Oprasional (BOPO), dan Financing to Deposite Ratio (FDR) dalam menjelaskan variabel dependen yaitu profitabilitas perusahaan Return On Asset (ROA) adalah sebesar 35,2\% sedangkan sisanya sebesar 64,8\% dijelaskan variabel lain yang tidak termasuk dalam penelitian. 


\section{Daftar Pustaka}

Bank Indonesia. 2005. “Laporan Perkembangan Perbankan Syariah”. Dalam http://www.bi.go.id

Bank Indonesia. 2007. "Lampiran Surat Edaran No. 9/24/DPbS Perihat Sistem Penilaian Tingkat Kesehatan Bank Syariah." Dalam http://www.bi.go.id

Bank Indonesia. 2007. "Surat Edaran No. 9/24/DPbS Perihat Sistem Penilaian Tingkat Kesehatan Bank Syariah.” Dalam http://www.bi.go.id.

Bank Indonesia. “Laporan Keuangan Publikasi Bank Umum Syariah.” Dalam http://www.bi.go.id.

Bank Indonesia.2008. “Laporan Perkembangan Perbankan Syariah.” Dalam http://www.bi.go.id

Bank Indonesia .2009. “Laporan Perkembangan Perbankan Syariah”. Dalam http://www.bi.go.id

Bank Indonesia. 2010. “Laporan Perkembangan Perbankan Syariah.” Dalam http://www.bi.go.id

Dendawijaya, Lukman. 2003. Manajemen Perbankan. Jakarta: PT Ghalia Indonesia.

Hasbi, Hariandy dan Tendi Haruman. 2011. "Banking: According to Islamic Sharia Concepts and Its Performance in Indonesia." International Review of Business Research Papers, Vol. 7, No. 1, pp. 60-76.

Mudrajad Kuncoro. 2002. Manajemen Perbankan: Teori dan Aplikasi. Yogyakarta : BPFE. Hlm. 462.

Mahardian, Pandu. 2008. "Analisis Pengaruh Rasio CAR, BOPO, NPL, NIM, dan LDR terhadap Kinerja Keuangan Perbankan (Studi Kasus Perusahaan Perbankan yang Tercatat di BEJ periode Juni 2002 - Juni 2007)”. TesisProgram Pasca Sarjana Magister Manajemen Universitas Diponegoro.http.//eprints.undip.ac.id

Muhammad, 2005.Manajemen Bank Syariah.Yogyakarta: UPP AMP YKPN

Nusantara, Ahmad Buyung. 2009. “Analisis Pengaruh NPL, CAR, LDR, dan BOPO terhadap Profitabilitas Bank (Perbandingan Bank Umum Go Publik dan Bank Umum Non Go Publik di Indonesia Periode Tahun 20052007). ’Tesis Program Pasca Sarjana Magister Manajemen UniversitasDiponegoro. http.//eprints.undip.ac.id

Yuliani. 2007. "Hubungan Efisiensi Operasional dengan Kinerja Profitabilitas pada Sektor Perbankan yang Go Publik di Bursa Efek Jakarta.” JurnalManajemen dan Bisnis Sriwijaya, Vol. 5, No. 10, pp. 15-43 